\title{
The Use of English on Instagram Captions: A Case Study in Camera Indonesia Photography Community
}

\author{
Tutut Nani Prihatmi' ${ }^{1}$, Rini Anjarwati², Puji Rahayu ${ }^{3}$ \\ 1,2Department of Mechanical Engineering, National Institute of Technology Malang, \\ Indonesia \\ ${ }^{3}$ Department of Magister of English Education, Islamic University of Malang, \\ Indonesia \\ tutut.nani@lecturer.itn.ac.id
}

\begin{tabular}{ll}
\hline Article History & Received : June $9^{\text {th }} 2021$ \\
& Revision : August $13^{\text {th }} 2021$ \\
& Publication : Sept 30th 2021 \\
\hline
\end{tabular}

\begin{abstract}
Along with Instagram's growing popularity as the primary medium for sharing photos and videos, the world of photography is also expanding at a rapid pace. Instagram caption is always dropped every time people upload on social media. Photo captions often act as a result of critical thinking and a way to communicate ideas. This study used a qualitative descriptive approach to collect and describe information about the using English caption on Instagram photos from the perspectives of Camera Indonesia photography community members: frequency, purpose for dropping captions in English, its effect on their photo works, and how they view English captions on others people' photo captions. Using 10 members as the respondents, the study found that writing caption in English act mostly as a selfexpression and has not yet done on the daily basis as the respondents do not habituate reading English materials.
\end{abstract}

Keywords: English caption, Instagram, photography community.

\section{INTRODUCTION}

Industry 4.0 era has allowed the massive use of technology-based application and emphasizes on digitalization. This leads to the emergence of various types of social media or accounts in cyberspace and new applications that greatly affect social communication. Social media was created to make communication easier (Silubun 2019). Everyone in any part of the world can connect more easily with a variety of options. Social media is a fun and comfortable way to stay connected more easily with friends or family as it is a representation of each user image and social circle (Prihatmi, 2018). One of the most famous social media at this time is Instagram which is owned by Facebook. Instagram concerns in sharing photos, videos, stories, lives, and shopping items (Zakirah, 2020) and continuously updated to recent features. With the number of users reaching one billion monthly active users and with various photo editing features offered, Instagram then becomes a place to form a self-image as they want to be recognized by the public (Zakirah, 
2020). The more the number of followers or followers and likes in the photo of the account owner, the more it will be seen that the user has a high self-image.

Along with the growing popularity of Instagram as the main medium for sharing photos and videos, the world of photography is also growing very rapidly. Currently, there are more photography enthusiastic form their own community, one of which is Camera Indonesia. Camera Indonesia is one of the photography communities in Indonesia which was established in Bali in 2015. Camera Indonesia is a community for photo hunting, sharing photography techniques, sharing photography experiences, and fostering people who are new to the world of photography to understand and become more proficient after joining them. Up to March 2021, there are 96,5K posts uploaded under their respective Instagram tag for their members, namely \#ci_member.

Nowadays, as social media become part of life, users commonly share a picture with a text below using a variety of English writing styles. Grayam (2010) states that a text written below an image is known as captions or a cut line. Caption consists of additional information which available in the pictures/photos. In general, the purpose of the caption is to help readers or viewers to understand more information that might not be in photos or videos. A caption can be an information of where, when, and by whom it was taken, found, or executed. Grayam (2010) stated that there are five elements in writing a caption, includes clarity, conciseness, relevant, context and attractiveness. A previous research by Maulina (2018) investigating students' abilities in writing caption on Instagram found that their ability in use English captions is good enough, although there were still some language elements need to be improved. She found that the writing of captions needs to be based on the existence of critical and creative thinking so that the images and writing will be connected. Another research by Nurhantoro and Wulandari (2017) found out 24\% from 100 respondents stated that interacting with the native speakers using English through Instagram will influence the users' pride and it has the possibility to lead them to regard western culture superior than theirs. While Amirudin and Triyono (2018) stated that caption is deeply incorporated with communicative intentions of its users implicitly or explicitly which is mostly addressed to others.

In line with the results of the previous studies, photo captions often act as a result of critical thinking and a way to communicate ideas. For photographers, a photo caption is an important part of their photo works. Some of them even need to put more efforts in writing a caption. One example is the caption on Instagram written by a member of Camera Indonesia by account @friska.pra:

"Write a caption...boleh ga sih captionnya nyusul? Bikin caption itu susyah banget. Seringkali stok foto banyak, captionnya gada sama sekali. Adakah yang 
mengalami hal yang sama? (Write a caption...can the caption follow suit? Making captions is really hard. Often times, there are a lot of stock photos, but the caption is not there at all. Is there anyone experiencing the same thing?"

Therefore, this research aims to be able to understand the use of English captions on Instagram photo works by Camera Indonesia community members, the purpose for dropping captions in English, its effect on their photo works, and how they view others' English captions

\section{METHOD}

This research is a case study that used qualitative descriptive approach as it tried to collect and describe information related to social aspects in a photography community. Qualitative research is an open assumption where the observational subject and the observer is part of the study itself (Manicas \& Secord in Padgett, 2017). Therefore, the research instruments in qualitative methods are the researchers themselves (Gunawan, 2013). The data collection technique employed was online questionnaire and document observation. The sampling used purposive method, that is, selecting respondents based on their ability to provide the required information (Padgett, 2017). The subjects of this research were 11 members of Camera Indonesia in Malang and National Room. There were three indicators used in the questionnaire: frequency, purpose, and effect. Data analysis stages included descriptive data collection, data display and coding, data reduction, conclusion withdrawal, and verification (Gunawan, 2013).

\section{RESULTS AND DISCUSSION Results}

To begin with, this study was conducted based upon the following respondent demography. There were 11 respondents all together including both female by $36,4 \%$ and male by $63,6 \%$. Their educational background ranging from high schools to tertiary levels consecutively; post graduate (S3) by $9.1 \%$, (S2) by 9,1\%, 36,4\% were under graduates (S1), and the highest number was the high schoolers by $45,5 \%$.

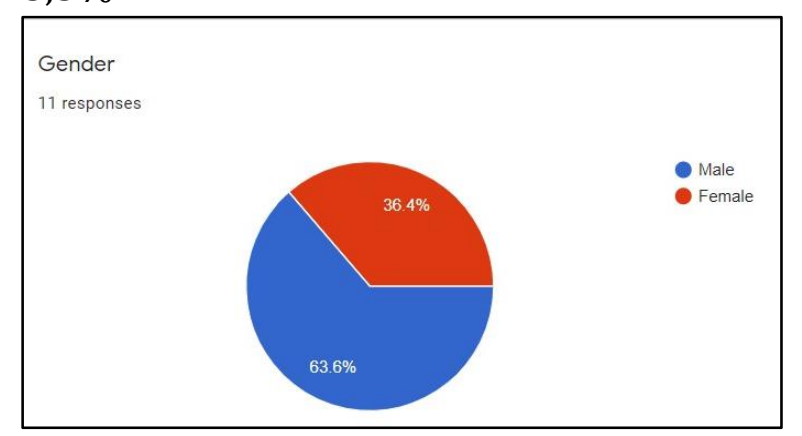

Fig 1. (a). Respondent's gender

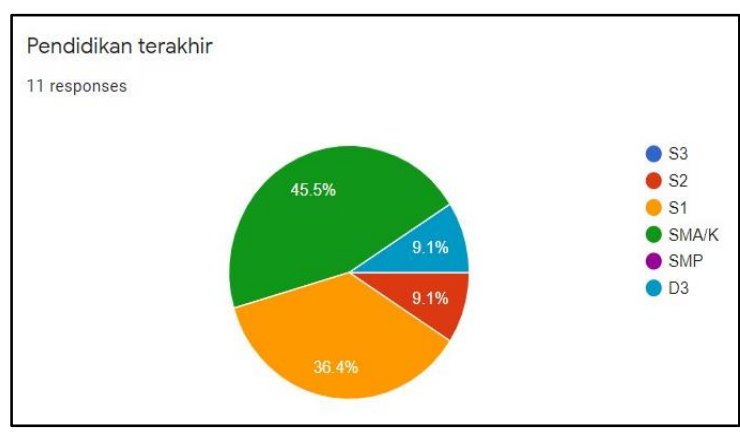

(b). Respondents Educational Background 
The questionnaire of the survey was conducted based on the following initial aspects of the study. Question number one is about frequency. The result shows that most respondents by 54,5\% reasonably frequent to writing caption in English. The other $18,2 \%$ fall into two categories the one less frequent and almost never write caption in English. The last figure that was by $9.1 \%$ of respondent always write in English.

1. Saya menulis takarir (caption) foto IG saya dalam Bahasa Inggris

11 responses

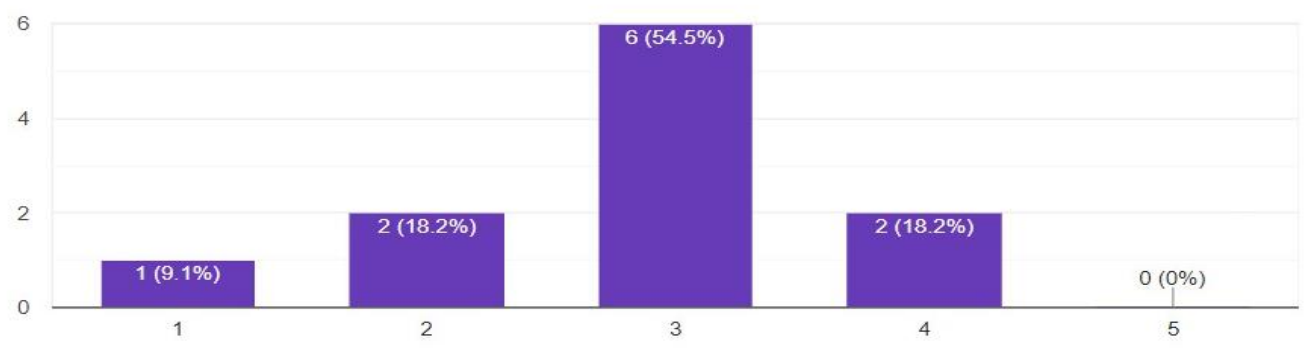

Fig 3. Frequency in using English caption

The second question, the respondents were asked about how frequent they are exposed on either English literature like novel, comics, books or motion pictures like movie, drama, video, TV series. As shown in Figure 4, 27,3\% of the respondents said that they often read materials and watch movies or drama in English. There was $9,1 \%$ of the respondent said that he less frequent to read or watch things in English. The other respondent by 18,2\% almost never read or watch movies in English. However, the highest number that is by $36,4 \%$ said that they pretty frequent either read or watch motion pictures and only $9,1 \%$ of the respondents is neither read nor watch movies or videos in English.

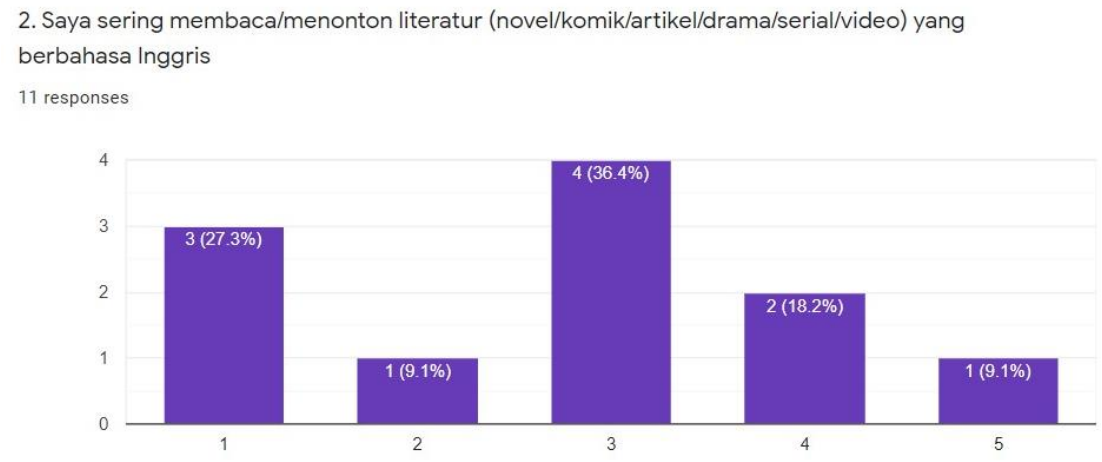

Fig 4. Frequency in reading or watching literature in English 
In regard of the second question, Figure 5 showed that English material the respondent most encountered by $60 \%$ was YouTube video and the rest consecutively fall for drama series by $20 \%, 10 \%$ for scientific articles, and the other $10 \%$ was for comics.
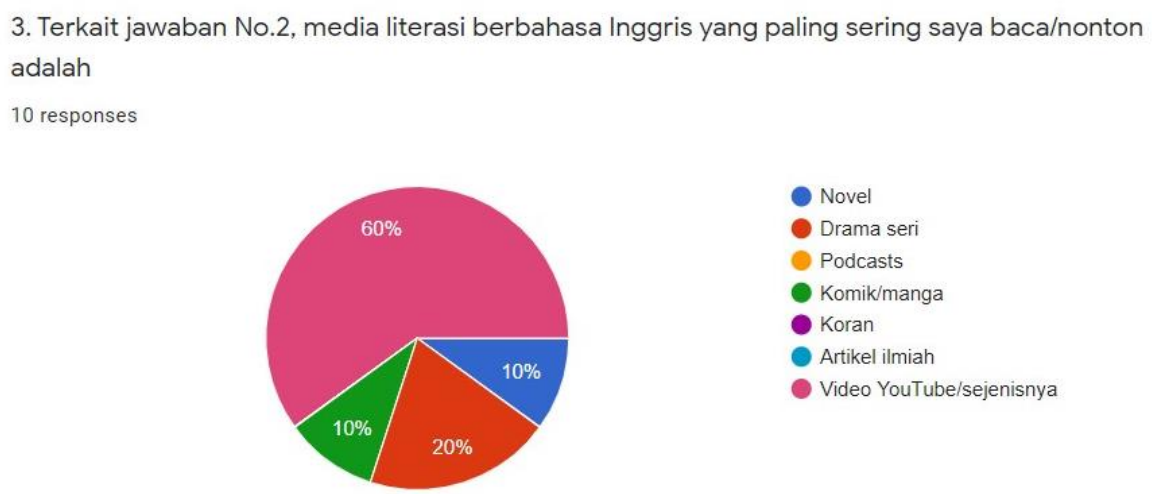

Fig 5. English material most encountered by respondents

Furthermore, the purpose of writing caption is the next aspect of the study. Figure 6 showed that most respondents by $45.5 \%$ stated that they wrote caption in English for self-expression. While the other 36,4\% thought that was for extended coverage viewer. The respondent by $27.3 \%$ write caption in English was as the English learning media. The last respondent by $9.1 \%$ said that he wrote caption in English because his followers are not only the locals.

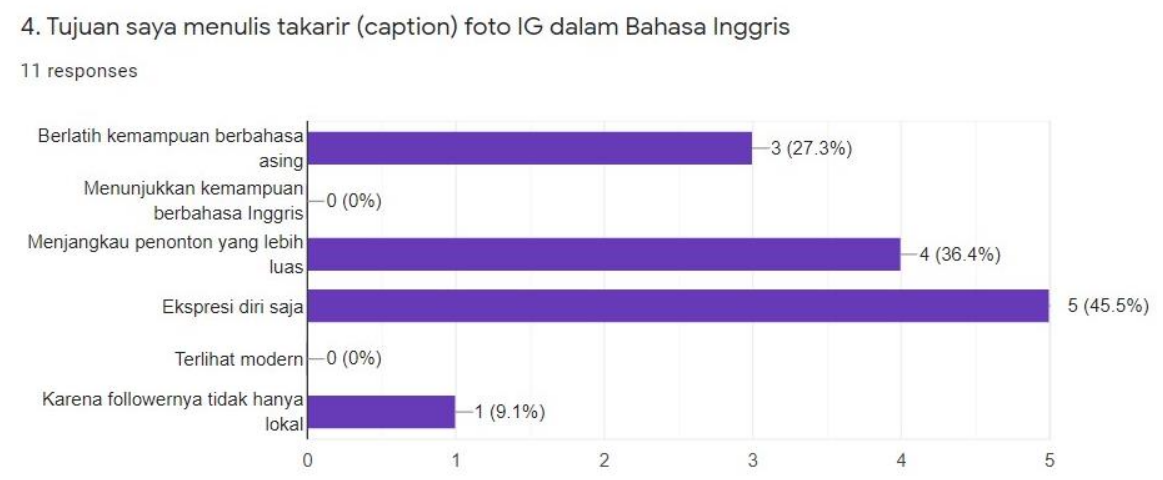

Fig 6. Purpose in writing English caption

The fifth question of the questioner was about the respondent's perspective to the individuals writing caption in English. Most of the respondents by $45.5 \%$ appreciated very much those who wrote caption in English. The second highest respondent were less appreciative and only $18.2 \%$ was pretty appreciate the ones 
wrote caption in English. None of the respondents were depreciative people's writing caption in English.

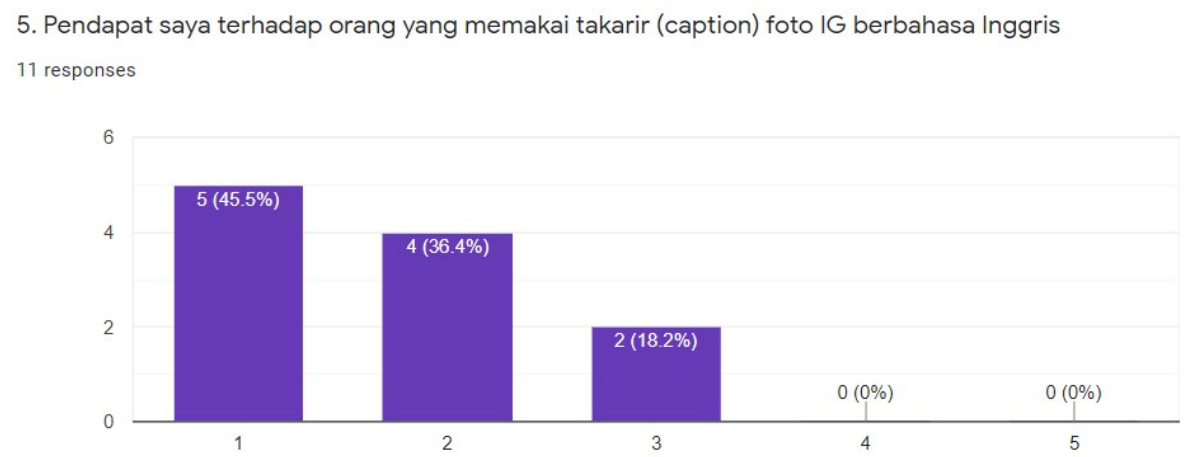

Fig 7. Respondent's perspective to the individuals writing English caption

Question 6. The impact on using English caption on the respondents' photo works

The last question arisen was about the effectiveness of using caption in English toward the respondent's photo work uploaded. The responses were positive, varied, and quite different from each other such as they could reach broaden viewers, more personalized, and enabled them to view and interact with international audience. One respondent stated that the pictures could speak more since it told information about the picture especially for foreign people. Despite more responses sounded positivity, there were two respondents stated that there was no significant effect of writing caption in English on the pictures they uploaded.

\section{Discussion}

The result of the study indicates that most of the respondents wrote caption in English was on a reasonable frequency meaning that they did not always write caption in English over the photo work they uploaded. In fact, it correlated with the low frequency of reading English literature since their exposure of English was more on watching YouTube video. However, the purpose of writing caption in English contradicts with the claim of Nurhantoro and Wulandari (2017) stated that writing caption in English was a media to interact with native speaker, this study suggested that the main purpose of writing caption in English was more on the self-expression. The last aspect to be studied was the effectiveness of the caption toward the photo work uploaded. The data contributes a various understanding of how effective writing caption in English in the sense of others perspective over the photo work being uploaded on IG feed. Like the previous study proposed by Amirudin and Triyono (2018) that writing caption accommodated communicative approach with others, this study found out that writing caption in English is one way to communicate with broaden active users of IG. However, for further study, bigger chunks of respondents will be advisable in regard of stronger validity of the findings. 


\section{CONCLUSION}

All in all, writing caption in English has not yet done on the daily basis due to the fact that the respondents do not habituate reading English material. Their English exposure merely more on YouTube videos. It then relates to the purpose of writing ones in English for personal issue other than broaden viewer coverage.

\section{REFERENCES}

Amirudin, Triyono, S. (2018). Expositive Acts on Instagram: Knowing What People Intent to "Write" on their Captions through Pragmatics Perspective. International Journal of Applied Linguistics \& English Literature, Vol 7 (4)

Padgett, D. K. (2017). Qualitative Methods in Social Work Research, $3^{\text {rd }}$ Edition. New York: SAGE Publications, Inc. 28-154

Prihatmi, T.N. (2018). Pengaruh Media Sosial terhadap Prestasi Belajar Bahasa Inggris pada Program Studi Teknik Mesin ITN Malang. Jurnal Flywheel, Vol 9(1) https://doi.org/10.47549/flywheel.v9i1.2555

Gunawan, Imam. (2013). Metode Penelitian Kualitatif. Bumi Aksara. Jakarta. 10-20

Grayam, L. 2010. Writing Photo Captions, Redbubble Artistic Journal, (Online),(https://www.redbubble.com/people/grayam/journal/4742583writing-photo-captions, accessed 26 February 2017).

Nurhantoro, T.S, Wulandari, N. (2017). Exploring the Use of English In Instagram and Its Influence on the User's Identity. Journal of English Language and Education, vol 3(2).

Malina, C.R, et al. 2018. An Analysis of Students' Ability in Writing Caption Through Instagram. Research in English Education (READ), 2(February), 227-249.

Silubun, I.Y. (2019). Komunikasi Sosial di Era Industri 4.0. https://www.beritasatu.com/opini/6334/komunikasi-sosial-di-era-industri$\underline{40}$

Sugiyono. (2010). Metode Penelitian Pendidikan Pendekatan Kuantitatif, Kualitatif, dan $R \& D$. Bandung: Alfabeta

Zakirah, D. M. A. (2020). Media Sosial Sebagai Sarana Membentuk Identitas Diri Mahasiswa Universitas Airlangga Surabaya. Jurnal Kopis: Kajian Penelitian Dan Pemikiran Komunikasi Penyiaran Islam,2(2), 91-105. https://ejournal.iaitribakti.ac.id/index.php/kopis/article/view/1116 